\title{
11. A SEDIMENTOLOGICAL, FAUNAL, AND ISOTOPIC RECORD OF THE MIDDLE-TO-LATE PLIOCENE TRANSITION IN THE NORTHEASTERN ATLANTIC, DEEP SEA DRILLING PROJECT SITE 5481
}

\author{
Paul Loubere and Richard Jakiel, Department of Geology, Northern Illinois University²
}

\begin{abstract}
Hydraulic piston coring at DSDP Site 548, on the upper continental slope southwest of Ireland, recovered a nearly complete Pliocene section spanning $103 \mathrm{~m}$ of sediment. The sediments are greenish gray carbonate-rich hemipelagites containing abundant nannofossils and foraminifers. Grain-size analysis demonstrates that the texture of the section is fairly constant, with most of the variation occurring in $63-$ to $32-\mu \mathrm{m}$ and $<2-\mu \mathrm{m}$ fractions. Previous research has shown that the middle-to-late Pliocene transition in the North Atlantic was marked by the appearance of the planktonic foraminiferal species Globorotalia inflata and by the first occurrence of significant quantities of ice-rafted sediment grains in deep-sea sediments. The latter is taken to represent the first important development of Northern Hemisphere glaciation. The first appearance of $G$. inflata is carefully documented for Site 548 and is demonstrated to be an evolutionary datum at this site, rather than an ecologically controlled first appearance. Surface ocean conditions represented in the sediment section spanning the appearance of $G$. inflata were strongly cyclic, resulting in large periodic changes in the abundances of Globorotalia puncticulata and $N$. acostaensis. The benthic foraminiferal population was studied in detail over the middle-to-upper Pliocene transition to establish the nature and behavior of the intermediate-depth water mass in the northeastern Atlantic at the time of ice-sheet growth in the Northern Hemisphere. This water mass is presently warm and saline, having its source in the Mediterranean Sea. The benthic data show that the intermediate-depth water mass was undergoing a series of progressive changes over the interval including the first appearance of $G$. inflata. These changes are particularly reflected in the relative abundances of Globocassidulina subglobosa (Brady), Uvigerina, and Ehrenbergina. Also, the mean size of individuals in the G. subglobosa populations shows systematic variation, indicating changing intermediate-depth water properties. Oxygen-isotope analyses show that the intermediate-depth water mass was cold during the middle-to-late Pliocene transition. This interpretation is supported by the relative abundances of benthic foraminiferal species. Hence, the intermediate-depth northeastern Atlantic water mass of the middle to late Pliocene was considerably different from the intermediate-depth water mass of the present.
\end{abstract}

\section{INTRODUCTION}

The purpose of this chapter is to establish the characteristics of the Pliocene sediments at DSDP Site 548 and to examine the paleoceanic record preserved in these sediments. We present first a sedimentological description of the nearly complete Pliocene section recovered on Leg 80 at Site 548, and then offer a detailed examination of the first appearance of the planktonic foraminifer Globorotalia inflata (d'Orbigny). We also present a detailed examination of the variation in planktonic and benthic foraminiferal taxic abundance over the interval where $G$. inflata appears in the sediment record of Site 548. These data are accompanied, finally, by benthic oxygen-isotope analyses, which help establish bottom-water properties for the site.

The $G$. inflata datum is important because Poore (1981) and Berggren (1972b) have shown that it is associated with the first occurrence of significant quantities of ice-rafted sand in deep-sea sediments from all parts of the North Atlantic. Hence, the species appearance can be tied to a period of significant expansion of Northern Hemisphere polar ice. Our purpose is to establish that the Pliocene section at Site 548 is suitable for paleoceanic studies and to establish the nature of

\footnotetext{
${ }^{1}$ Graciansky, P. C. de, Poag, C. W., et al., Init. Repts. DSDP, 80: Washington (U.S. Govt, Printing Office)

2 Address: Dept. of Geology, Northern Illinois Univ., DeKalb, IL 60115.
}

surface and bottom waters at the time of the middle-tolate Pliocene transition when the ice sheets first expanded. Following Stainforth et al. (1975), we define the middle/upper Pliocene boundary as marked by the first occurrence of $G$. inflata.

\section{SEDIMENTOLOGICAL DESCRIPTION OF THE PLIOCENE SECTION}

Site 548 is southwest of Ireland and directly west of Brittany, France, in $1251 \mathrm{~m}$ of water. The drilling location is an extension of the Western Approaches Basin and the English Channel (see Fig. 1 and the site chapter). The Plio-Pleistocene boundary occurs at about $108 \mathrm{~m}$ sub-bottom, and a nearly complete Pliocene section extending down to $211 \mathrm{~m}$ was recovered using the variablelength hydraulic piston corer. Sediments recovered are dominantly light greenish-gray nannofossil oozes $(5 \mathrm{G} 6 / 1$, $5 \mathrm{G} 8 / 1$, and $5 \mathrm{~B} 7 / 1$ ).

Figure 2 summarizes the lithostratigraphy of the Site 548 Pliocene. From 108 to $131 \mathrm{~m}$ sub-bottom, the section contains frequent evidence of deposition by bottom gravity flows. The evidence consists of sandy horizons, often normally graded, and frequent dark, very muddy intervals with low carbonate content $(20 \%)$.

From 131 to $211 \mathrm{~m}$ the section is dominantly hemipelagic ooze containing abundant carbonate (generally 50$70 \%$ ). There is evidence for occasional current winnowing, or gravity-flow deposition, in the form of thin (1-2 $\mathrm{mm}$ ) silty partings or burrows partly filled with fine- 

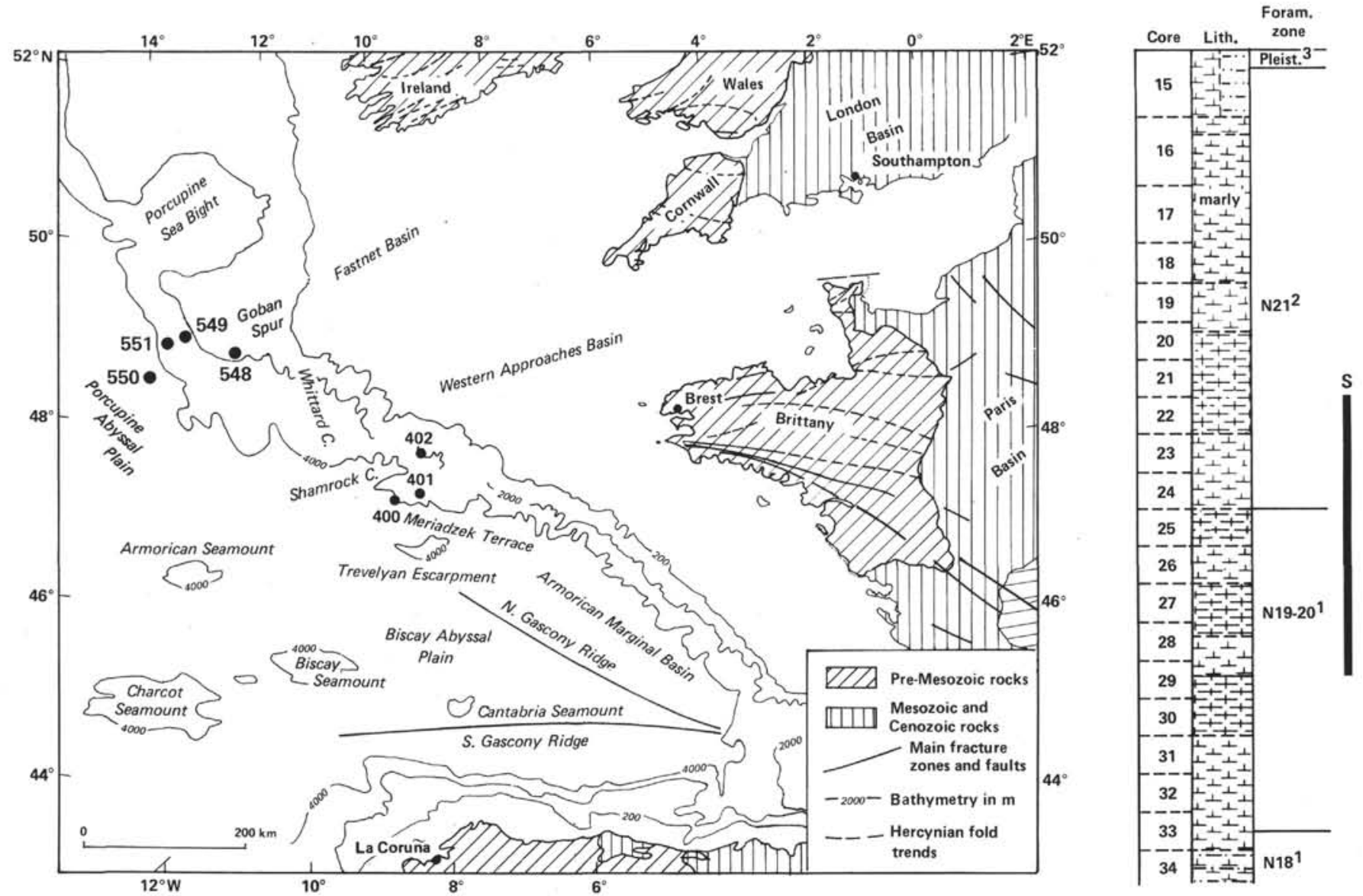

Figure 1. Location of Site 548, southwest of Ireland, on the upper continental slope of the northeastern Atlantic. Also shown is a stratigraphic column of the Pliocene at Site 548. S = interval studied in this paper. Planktonic foraminiferal zone determinations are as follows: (1) Snyder and Waters, this vol.; (2) after Poore (1979), based on the occurrence of $G$. inflata as reported in this paper; (3) shipboard scientists. Symbols for lithology as defined in Explanatory Notes (this vol.).

grained sand or silt. These are not common, and comprise only a very small fraction of the Pliocene section (see Fig. 2).

More important in the section are intervals where the ooze coarsens somewhat (see Fig. 2). These intervals are unusual in that they are not marked by any color changes or sedimentary structures, and the boundaries between coarser and finer horizons are nearly all completely gradational. The coarsening is not dramatic, but is quite noticable when the sediment is rubbed on a sampling spatula. Coarser horizons are most common between 175 and $194 \mathrm{~m}$, but they occur throughout the section. Between 134 and $141 \mathrm{~m}$ a different sediment lithology is recorded in the form of several horizons of greenish gray ooze, which are conspicuously darker than the surrounding sediment and have a noticeably higher clay content (Fig. 2).

\section{PARTICLE-SIZE ANALYSIS}

Twenty-one particle-size analyses (locations on Fig. 2) were used to define the textural variation that occurs in the previously described hemipelagite. These are presented in Table 1 . The measurements were performed following the procedures of Royce (1970). Four samples were reanalyzed to establish repeatability of analysis; the results indicate a precision of about $2 \%$. The data in Table 1 show that the sediment is fairly uniform in texture, but that there is significant variation in the 63- to $32-\mu \mathrm{m}$ and $\langle 2-\mu \mathrm{m}$ fractions. The coarser intervals in the section are enriched in the 63- to $32-\mu \mathrm{m}$ fraction, and contain correspondingly less material in the $<2-\mu \mathrm{m}$ fraction. Microscopic examination of the 63- to $32-\mu \mathrm{m}$ fraction shows that it is composed largely of subangular quartz and carbonate grains. The coarser intervals in the hemipelagite therefore probably represent brief influxes of terrigenous silt to a hemipelagic setting. There is no evidence for transport of this material by traction or density current, so the "shelf spillover" mechanism of Doyle et al. (1979) is the mostly likely depositional agent.

The foregoing data show that most of the Pliocene section at Site 548 was deposited by pelagic settling of grains and microfossils. The influence of density currents was minimal. Significant textural variation occurs at grain sizes smaller than is often used for paleoceanic research based on foraminifers ( $>150 \mu \mathrm{m})$. Hence, the foraminiferal population should be largely "autochthonous." For the samples examined in this chapter, the $>150-\mu \mathrm{m}$ fraction is composed almost entirely of foraminifers. 


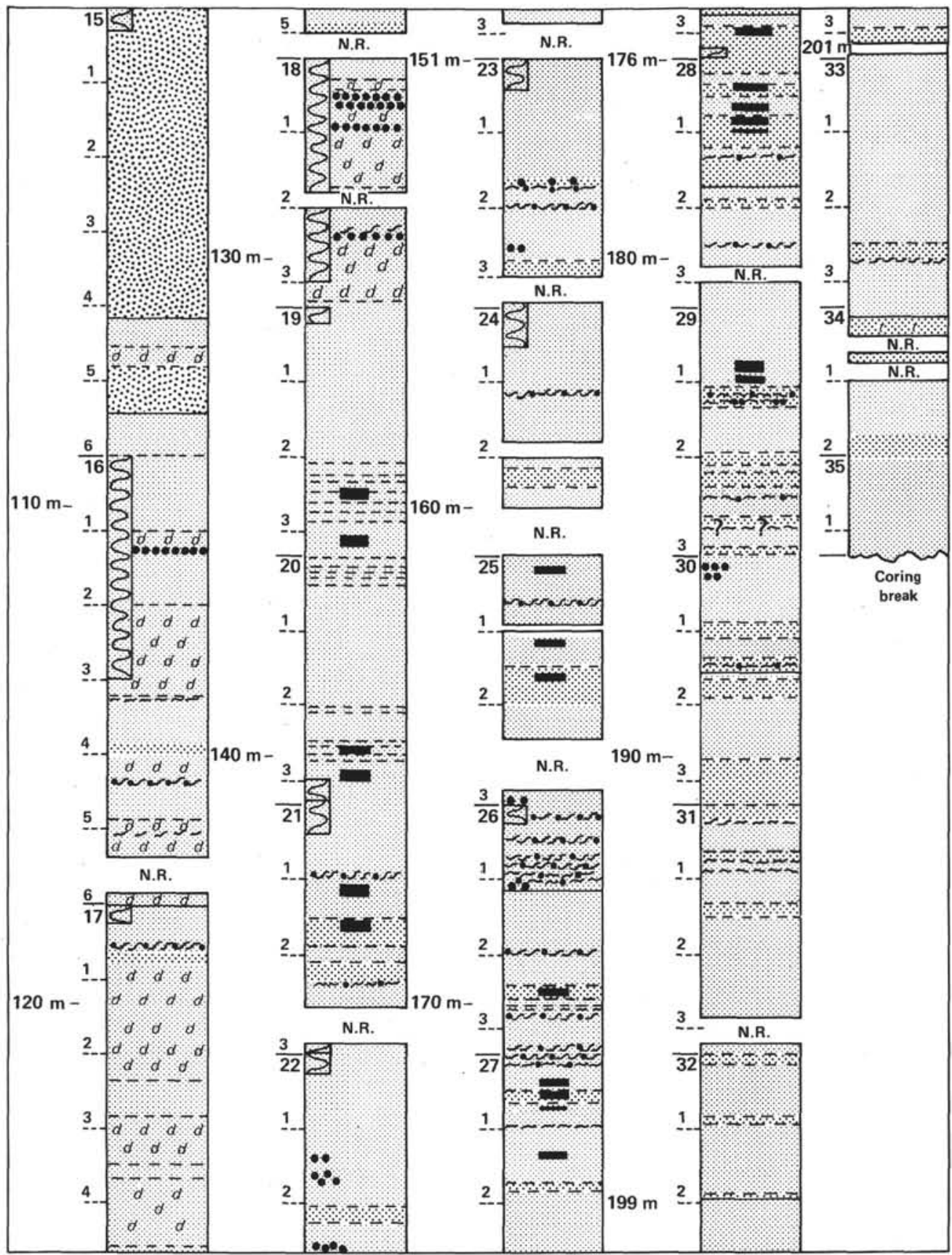

Figure 2. Lithostratigraphy of the Pliocene at Site 548. Largest numbers indicate sub-bottom depth; next largest numbers are core numbers, and smallest numbers designate sections. Fine stipple $=$ dominant greengray calcareous hemipelagite. Intermediate stipple $=$ horizons of somewhat coarser hemipelagite. Heavy stipple $=$ alternating sandy graded beds and beds of silt and mud. $d=$ dark brown olive mud. Dashed pattern $=$ horizons where gray-green hemipelagite has a higher clay content and a somewhat darker color. Dots $=$ silty partings and/or silt-filled burrows. $\mathrm{t}=$ apparently higher terrigenous content. Black rectangles = sampling locations for grain size. The vertical sinuous line in $1 / 4$ of the core section $=$ sediment deformed by piston coring. N.R. = no recovery.

\section{THE FIRST APPEARANCE OF GLOBOROTALIA INFLATA}

In the North Atlantic, $G$. inflata is presented as evolving from and gradually replacing Globorotalia puncticulata (Deshayes) (Poore, 1979, 1981). Illustrations of both species are presented by Poore (1979). Photomicrographs of upper Pliocene and lower to upper Pleistocene specimens of $G$. inflata from Sites 548 and 549 (which is adjacent to Site 548) are given in Plate 1. G. inflata was distinguished from $G$. puncticulata on the basis of four characters. These are the shape of the dorso-peripheral shoulder, the aperture location and shape, the number of chambers in the final whorl as seen from the spiral side, and the texture. The ideal specimen of G. puncticulata (as figured by Poore, 1979, plate 5, figs. 4-6, and 
Table 1. Hole 548 Pliocene particle-size distributions (wt. \%).

\begin{tabular}{|c|c|c|c|c|c|c|c|c|}
\hline \multirow{2}{*}{$\begin{array}{l}\text { Core-Section } \\
\text { (level in } \mathrm{cm} \text { ) }\end{array}$} & \multicolumn{8}{|c|}{ Particle size $(\mu \mathrm{m})$} \\
\hline & $>149$ & $149-63$ & $63-32$ & $32-15$ & $15-8$ & $8-3$ & $3-2$ & $<2$ \\
\hline $19-3,80$ & 0.44 & 0.41 & 4.27 & 14.73 & 15.84 & 14.05 & 7.42 & 42.83 \\
\hline $19-4,25$ & 2.90 & 3.16 & 17.57 & 16.52 & 14.10 & 8.18 & 7.38 & 30.18 \\
\hline $20-3,94$ & $\begin{array}{c}2.26 \\
(2.18)^{\mathrm{a}}\end{array}$ & $\begin{array}{c}2.82 \\
(2.72)\end{array}$ & $\begin{array}{c}12.62 \\
(12.89)\end{array}$ & $\begin{array}{c}14.61 \\
(15.26)\end{array}$ & $\begin{array}{c}13.58 \\
(13.89)\end{array}$ & $\begin{array}{c}7.92 \\
(7.71)\end{array}$ & $\begin{array}{c}6.38 \\
(7.02)\end{array}$ & $\begin{array}{r}39.81 \\
(38.24)\end{array}$ \\
\hline $20-3,141$ & $\begin{array}{c}2.31 \\
(2.12)\end{array}$ & $\begin{array}{r}4.41 \\
(4.04)\end{array}$ & $\begin{array}{c}27.21 \\
(31.86)\end{array}$ & $\begin{array}{c}15.52 \\
(15.18)\end{array}$ & $\begin{array}{l}10.95 \\
(9.05)\end{array}$ & $\begin{array}{l}5.86 \\
(6.01)\end{array}$ & $\begin{array}{c}5.26 \\
(4.23)\end{array}$ & $\begin{array}{r}28.46 \\
(27.52)\end{array}$ \\
\hline $21-2,20$ & 2.32 & 4.31 & 22.38 & 14.02 & 9.79 & 10.54 & 3.96 & 32.66 \\
\hline $21-2,96$ & 4.00 & 10.95 & 32.65 & 14.01 & 5.66 & 6.83 & 4.66 & 21.24 \\
\hline $25-1,21$ & 1.52 & 3.61 & 26.40 & 13.38 & 9.79 & 10.27 & 6.58 & 28.50 \\
\hline $25-2,26$ & 2.64 & 4.88 & 31.15 & 13.01 & 8.13 & 9.12 & 5.89 & 25.17 \\
\hline $25-2,97$ & 1.72 & 4.63 & 35.90 & 13.30 & 7.54 & 7.66 & 5.25 & 24.00 \\
\hline $26-3,75$ & 3.44 & 6.44 & 31.76 & 14.12 & 7.50 & 6.89 & 4.28 & 25.58 \\
\hline $27-1,65$ & 1.10 & 5.28 & 20.46 & 12.77 & 8.71 & 10.76 & 8.00 & 32.92 \\
\hline $27-1,85$ & 1.32 & 5.15 & 31.26 & 15.24 & 9.14 & 8.93 & 7.16 & 21.80 \\
\hline $27-1,100$ & 1.30 & 3.40 & 18.20 & 12.79 & 12.52 & 10.06 & 7.43 & 34.29 \\
\hline $27-2,53$ & 0.54 & 1.59 & 16.67 & 14.70 & 13.73 & 11.21 & 7.24 & 34.40 \\
\hline $27-3,149$ & 1.34 & 5.45 & 30.10 & 8.60 & 10.31 & 8.79 & 7.11 & 28.40 \\
\hline \multirow[t]{2}{*}{$28-1,51$} & 1.38 & 5.78 & 40.70 & 14.19 & 7.54 & 6.61 & 5.40 & 18.39 \\
\hline & (1.27) & (5.32) & (42.36) & (14.31) & (6.80) & (5.62) & $(5.22)$ & (19.10) \\
\hline $28-1,104$ & 1.30 & 3.86 & 25.52 & 12.38 & 8.40 & 7.03 & 8.86 & 32.65 \\
\hline $28-1,124$ & 2.27 & 7.33 & 26.32 & 12.47 & 7.00 & 9.36 & 4.64 & 30.61 \\
\hline $28-1,145$ & 2.69 & 7.51 & 35.93 & 12.77 & 10.38 & 6.03 & 5.91 & 18.77 \\
\hline \multirow[t]{2}{*}{$29-1,128$} & 2.31 & 3.02 & 12.35 & 8.21 & 12.77 & 11.53 & 9.93 & 39.91 \\
\hline & - & - & (12.77) & (8.61) & (14.69) & (12.19) & (7.94) & (38.45) \\
\hline $29-1,147$ & 1.66 & 3.46 & 10.50 & 9.99 & 12.44 & 12.03 & 9.00 & 40.91 \\
\hline $\bar{X}$ & 1.94 & 4.64 & 24.28 & 13.21 & 10.28 & 9.03 & 6.56 & 30.07 \\
\hline S.d. & 0.90 & 2.25 & 9.59 & 2.10 & 2.76 & 2.18 & 1.63 & 7.17 \\
\hline
\end{tabular}

${ }^{a}$ Parentheses enclose values for the second run of the sample.

Stainforth et al., 1975, figs. 199 and 200) would have a high, angled shoulder, an interio-marginal-peripheral highly arched aperture, four chambers in the last whorl, and a puncticulate texture. The ideal $G$. inflata (Poore, 1979, plate 5, figs. 1-3; Plate 1) would have a low, rounded shoulder, a large umbilical to extra-umbilical aperture, about $3 \frac{1}{2}$ chambers in the final whorl, and a smooth to clear crystalline texture. As can be seen in Plate 1, the Pliocene and lower Pleistocene specimens from Site 548 have a crystalline texture, whereas upper Pleistocene specimens have a smooth test.

At Site 548, G. inflata appears over the span of Cores 548-25 and 548-24. G. puncticulata is abundant in these cores, and a considerable number of intergrades between the two species are also present.

To document the appearance of $G$. inflata and also to determine whether the appearance was evolutionary or controlled by a change in paleoceanic conditions (ecologic first appearance), samples were taken about every $50 \mathrm{~cm}$ through Cores 548-27 to 548-24, and relative abundances of planktonic species were determined for the $>150-\mu \mathrm{m}$ fraction. The counting techniques used are described in Loubere (1982), and have been demonstrated to provide good reproducibility. In all cases more than 300 individuals were counted (average of 387). Also, the relative abundances of $G$. inflata, G. puncticula$t a$, and their intergrades were determined. The relativeabundance data are presented in Table 2 and Figure 3. In Table 3 the types of $G$. inflata and $G$. puncticulata forms are quantified according to the criteria already listed; for this table about thirty well-formed individuals were carefully examined in a random transect across a counting slide. The table has the ideal $G$. inflata and $G$. puncticulata as end-members and a gradation of mor- photypes in between; from it one can form an impression of the degree and type of variability present in the populations examined. Following Stainforth et al. (1975), we gave primary consideration to the dorso-peripheral shoulder, which reflects overall test shape.

Table 4 presents the relative abundances of the dominant species from Cores 548-27 to 548-24 and the ratio of $G$. inflata and the intergrade forms to the sum of all the $G$. inflata and $G$. puncticulata morphotypes. It is evident from Tables 2 and 4 and Figure 3 that planktonic species abundances fluctuate regularly through Cores 548-26 to 548-24. Over this interval there are no indications of major unidirectional changes in surface ocean conditions, but instead there is recorded a regular oscillation between two conditions: one reflected in an assemblage of which the $G$. puncticulata-G. inflata group accounts for more than $20 \%$ of the specimens, and one reflected in an assemblage of which that group accounts for less than about $15 \%$ of the specimens. The ratio of G. inflata + intergrades to the sum of the G. puncticulata-G. inflata group remains uniformly low through Cores 548-26 and 548-25. The ratio shows no relationship to the fluctuating abundance of the G. puncticula$t a-G$. inflata group within the planktonic assemblage.

As shown in Table 3, Core 548-26 contains only G. puncticulata and intergrade forms close to the G. puncticulata morphotype. No individuals that could be called G. inflata were observed. In Core 548-25 the degree of morphotype variability increases considerably, and individuals that could be called Globorotalia cf. inflata were occasionally observed. Within Core 548-24 G. inflata forms become common to dominant. As seen in the planktonic-assemblage data (Table 2), there is no environmental change indicated that will explain this trend 


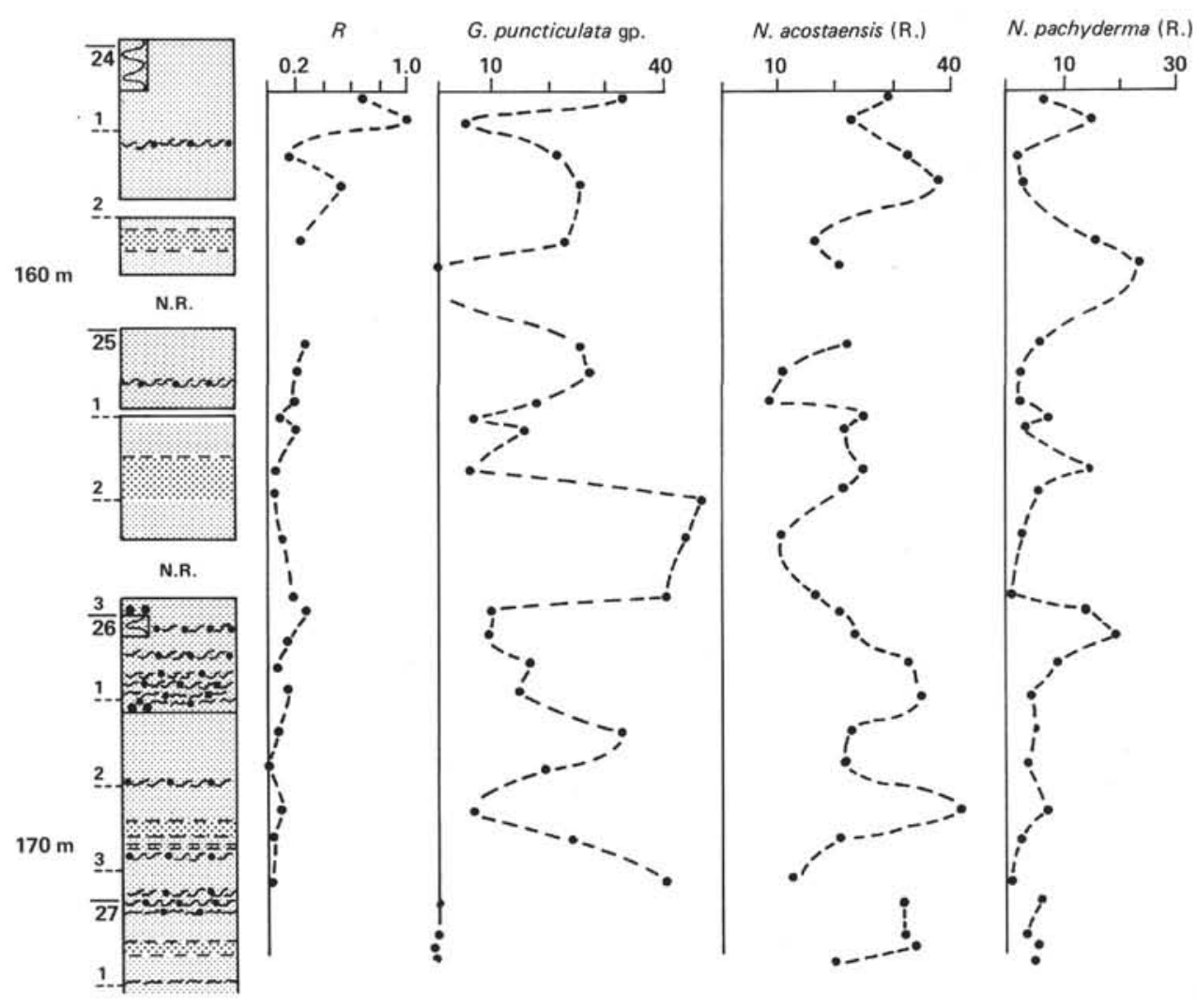

Figure 3. Relative abundances of planktonic foraminiferal species over the interval of the first occurrence of $G$. inflata. $R=$ abundance ratio of $G$. inflata and $G$. inflata-G. puncticulata intergrade to the sum of $G$. inflata, the intergrade, and $G$. puncticulata. $G$. puncticulata $\mathrm{gp} .=$ percent of $G$. inflata, the intergrade, and $G$. puncticulata in the planktonic assemblage. $N$. acostaensis $(\mathrm{R})=$. percent of rightcoiling $N$. acostensis (Blow). $N$. pachyderma $(\mathrm{R})=$. percent of right-coiling $N$. pachyderma (Ehrenberg). Stratigraphic column as in Figure 2.

in $G$. puncticulata-G. inflata morphotypes, so the record must represent an evolutionary sequence.

The exact age of this evolutionary event is is dispute. Berggren and Van Couvering (1974) place it at about 3 m.y. ago. Backman (1979) has disputed this on the basis of nannofossil correlations among DSDP sites in the higher-latitude North Atlantic. He would have the first appearance of $G$. inflata as late as $2.4 \mathrm{~m}$.y. ago. At Site 548 the record of this event occurs near the base of a long interval of normally magnetized sediments (Cores 548-19-548-26, Townsend, this vol.), which must be of the Gauss paleomagnetic epoch (2.5-3.4 m.y. ago, Ness et al., 1980). These data support the age proposed by Berggren and Van Couvering (1974). Further, an age of $2.4 \mathrm{~m}$.y. for the $G$. inflata datum would give the upper Pliocene at Site 548 (about 159.5-108 m sub-bottom on Fig. 2; shipboard scientists place the Plio-Pleistocene boundary at $108 \mathrm{~m}$ sub-bottom) a sediment accumulation rate of about $10 \mathrm{~cm} / 1000$ yrs. This is nearly twice the estimated Pleistocene accumulation rate of $5.7 \mathrm{~cm} /$ 1000 yrs. If the Pliocene estimate were correct, it would require the Pliocene planktonic-microfossil-rich hemipelagite to have accumulated much faster than the Pleistocene section, which contains abundant evidence of frequent deposition by density currents and turbidity currents. This is not likely, given our current understanding of the rates of deep-sea sedimentation. Again, these data support the age date of Berggren and Van Couvering (1974).

\section{CHARACTERIZING BOTTOM WATERS: BENTHIC FORAMINIFERS}

Site 548 was drilled at relatively shallow depths, so its benthic fauna represents the intermediate-depth water mass of the North Atlantic. Presently, this water mass is formed in the Mediterranean, and the sea-bottom around Site 548 is bathed by warm, saline water (Reid, 1978). Caralp (this vol.) shows that the Mediterranean water mass at Site 548 is identified by a benthic foraminiferal assemblage containing abundant Sigmoilopsis, Uvigerina peregrina (Cushman), Bulimina, and Melonis. To examine the benthic foraminiferal record over the middle-to-late Pliocene transition, calcareous specimens in the $>150-\mu \mathrm{m}$ fraction of 51 samples from Cores $548-29$ to $548-22$ were counted and apportioned to genera as defined by Loeblich and Tappan (1964) (see Fig. 4). In identifying specimens, reference was also made to Schnitker (1979b), Berggren (1972a), Pujos-Lamy (1973), and Murray (1971). In all samples save one (548-24-1, $100 \mathrm{~cm} ; 88$ individuals), at least 150 individuals were counted (average count was 387 individuals). In nearly all cases the entire population of benthic specimens was counted without sample splitting. The counts are presented in Figure 4, along with a record of average 
Table 2. Planktonic species abundances in samples spanning the F.A.D. of $G$. inflata, Hole 548.

\begin{tabular}{|c|c|c|c|c|c|c|c|c|c|c|c|c|c|c|}
\hline \multirow[b]{2}{*}{ Species } & \multicolumn{14}{|c|}{ Core-Section (level in $\mathrm{cm}$ ) } \\
\hline & $23-3,125$ & $24-1,100$ & $24-1,146$ & $24-2,50$ & $24-2,102$ & $24-3,45$ & $24-3,97$ & $25-1,21$ & $25-1,75$ & $25-1,125$ & $25-2,0$ & $25 \cdot 2,26$ & $25-2,97$ & $25-2,148$ \\
\hline Neogloboquadrina acostaensis $\mathbf{R}$. & $\underline{10.3}$ & 29.4 & $\underline{22.6}$ & 32.9 & $\underline{38.0}$ & 16.62 & $\underline{20.8}$ & $\underline{21.3}$ & $\underline{10.6}$ & $\underline{8.6}$ & 25.6 & $\underline{21.8}$ & 24.7 & $\underline{21.0}$ \\
\hline L. & - & - & 0.62 & 0.43 & 0.43 & 0.54 & 0.47 & 0.83 & 0.26 & 0.89 & 0.66 & - & 1.06 & 0.47 \\
\hline Neogloboquadrina atlantica $\mathbf{R}$. & 6.9 & 2.36 & $\underline{13.7}$ & 6.9 & 6.0 & 1.34 & 3.07 & 5.3 & 3.7 & 1.2 & 3.9 & 2.2 & 3.45 & 2.3 \\
\hline L. & 4.9 & 0.67 & 0.93 & 1.7 & 1.5 & 1.34 & 0.71 & 2.2 & $\underline{9.5}$ & $\underline{29.2}$ & $\underline{17.0}$ & 4.9 & 3.45 & 2.8 \\
\hline Neogloboquadrina pachyderma $\mathbf{R}$. & 5.9 & 6.42 & 14.5 & 2.2 & 2.6 & 15.0 & 23.4 & 6.1 & 2.9 & 2.4 & $\underline{7.2}$ & 3.9 & 14.6 & 5.6 \\
\hline Neogloboquadrina sp. $1^{\text {a }} \quad$ L. & $\overline{1.0}$ & $\overline{1.69}$ & $\begin{array}{l}0.15 \\
0.93\end{array}$ & $\overline{0.43}$ & $\begin{array}{l}0.43 \\
0.21\end{array}$ & $\begin{array}{l}0.27 \\
0.80\end{array}$ & 0.24 & $\overline{1.7}$ & $\overline{7.9}$ & $\begin{array}{c}0.30 \\
10.4 \\
\end{array}$ & $\begin{array}{l}0.33 \\
6.2\end{array}$ & $\overline{1.72}$ & $\begin{array}{l}0.27 \\
1.33\end{array}$ & $\overline{-}$ \\
\hline Globigerina woodii & 2.9 & - & 2.95 & 0.86 & 1.50 & 3.75 & 6.9 & 6.1 & $\overline{2.9}$ & $\overline{3.0}$ & 3.6 & 1.47 & 2.13 & - \\
\hline Globigerina bulloides $^{\mathrm{a}}$ & 4.0 & 4.73 & $\underline{11.0}$ & $\underline{8.67}$ & 1.9 & 3.22 & 5.4 & 6.6 & 4.2 & 0.90 & 1.6 & 1.96 & 6.38 & 0.47 \\
\hline Quadrate bulloides ${ }^{\mathrm{a}}$ & 2.3 & 1.02 & $\overline{4.4}$ & $\overline{2.2}$ & 1.1 & 1.88 & 1.89 & 3.6 & 7.7 & 3.87 & 3.3 & 2.45 & 3.46 & 2.8 \\
\hline $\begin{array}{l}\text { Inflated bulloides }{ }^{\mathrm{a}} \\
\text { Globigerina falconensis }\end{array}$ & $\begin{array}{l}0.33 \\
2.3\end{array}$ & $\overline{0.34}$ & $\begin{array}{l}1.6 \\
5.6\end{array}$ & $\begin{array}{l}0.87 \\
4.33\end{array}$ & $\overline{1.9}$ & $\begin{array}{l}0.54 \\
4.02\end{array}$ & $\begin{array}{l}0.24 \\
1.89\end{array}$ & $\overline{3.6}$ & $\begin{array}{l}0.79 \\
5.5\end{array}$ & $\begin{array}{l}0.60 \\
2.7\end{array}$ & $\begin{array}{l}1.6 \\
3.0\end{array}$ & $\begin{array}{l}0.25 \\
1.23\end{array}$ & $\begin{array}{l}0.27 \\
1.33\end{array}$ & $\overline{1.4}$ \\
\hline Globigerina calida & - & 0.34 & 0.16 & 0.43 & - & - & - & 0.28 & - & - & - & 0.25 & 1.06 & - \\
\hline Globigerinella aequilaterulis & 2.3 & 0.67 & 0.62 & 1.73 & 0.43 & 0.80 & 0.71 & 0.28 & - & 0.30 & 0.33 & - & 1.60 & 0.93 \\
\hline Globorotalia inflata & $\underline{11.6}$ & 5.07 & 3.3 & - & 1.9 & 0.80 & - & - & - & - & - & - & - & - \\
\hline Globorotalia bononiensis $^{\mathrm{a}}$ & $\overline{2.0}$ & 3.72 & - & 1.73 & 2.1 & 2.15 & - & 0.55 & 0.79 & 0.60 & 0.33 & 0.98 & - & 1.9 \\
\hline $\begin{array}{l}\text { Globorotalia inflata-Globorotalia } \\
\text { puncticulata (intergrades) }\end{array}$ & $\underline{11.6}$ & $\underline{16.89}$ & 2.0 & 4.3 & $\underline{11.9}$ & 5.09 & - & 8.0 & 5.3 & 4.2 & 0.98 & 3.92 & 0.53 & 2.8 \\
\hline Globorotalia puncticulata & $\underline{11.6}$ & $\underline{10.8}$ & - & $\underline{17.3}$ & $\underline{11.8}$ & $\underline{16.89}$ & - & $\underline{17.5}$ & $\underline{22.4}$ & $\underline{13.9}$ & 5.9 & $\underline{11.52}$ & 5.32 & 44.4 \\
\hline Globigerinita naparimaensis & 4.0 & 1.69 & 0.16 & $\overline{1.3}$ & 3.0 & 2.14 & 3.3 & $\overline{2.5}$ & 0.53 & 0.30 & 0.66 & 0.49 & 1.33 & 0.47 \\
\hline Globigerinita glutinata & 7.9 & 4.05 & 5.9 & 3.0 & 4.3 & $\underline{7.24}$ & 6.62 & $\underline{7.5}$ & 5.3 & 3.6 & 5.6 & 8.08 & 6.65 & 6.5 \\
\hline Globigerina quinqueloba & 3.6 & 6.42 & 1.6 & 1.3 & 1.1 & 2.14 & 8.03 & 0.55 & 1.0 & 4.5 & 3.9 & 8.08 & 3.46 & - \\
\hline $\begin{array}{l}\text { Globorotalia scitula } \\
\text { Globorotalia crassaformis }\end{array}$ & $\begin{array}{l}0.33 \\
1.3\end{array}$ & 0.68 & $\begin{array}{l}3.7 \\
0.62\end{array}$ & $\begin{array}{l}0.43 \\
1.73\end{array}$ & $\begin{array}{l}1.7 \\
2.6\end{array}$ & $\begin{array}{r}1.88 \\
11.26\end{array}$ & $\begin{array}{l}0.95 \\
13.2\end{array}$ & $\begin{array}{l}0.83 \\
3.3\end{array}$ & $\begin{array}{l}2.64 \\
3.2\end{array}$ & $\begin{array}{l}1.5 \\
1.8\end{array}$ & $\begin{array}{l}1.6 \\
0.66\end{array}$ & $\begin{array}{l}1.23 \\
6.86\end{array}$ & $\begin{array}{l}1.86 \\
8.78\end{array}$ & $\begin{array}{l}0.93 \\
1.87\end{array}$ \\
\hline Globorotalia praehirsuta & - & - & $\begin{array}{ll}0.02 \\
-\end{array}$ & - & - & - & 0.24 & - & - & 3.87 & 2.6 & 12.0 & $\overline{2.39}$ & - \\
\hline Orbulina universa & 1.7 & 1.01 & 1.9 & 2.6 & 2.6 & 0.27 & 1.42 & - & 1.1 & 0.30 & 0.33 & 3.68 & 3.46 & 3.3 \\
\hline Globigerina venezuelana & 0.33 & 1.35 & 0.3 & 2.2 & - & - & - & - & 1.1 & 0.60 & 1.3 & 0.49 & 0.79 & - \\
\hline Globigerina apertura & - & - & - & - & - & - & - & - & - & - & - & - & - & - \\
\hline
\end{tabular}

${ }^{a}$ These forms are discussed in the Appendix.

specimen length in the populations of Globocassidulina subglobosa. All specimens of G. subglobosa in the samples were measured along their longest axis for this statistic.

The genera presented in Figure 4 account for between 80 and $95 \%$ of the benthic assemblages. The most abundant genera are Globocassidulina, Cibicidoides, Melonis, and Bulimina. Contamination by shallower-water species appears to be minimal, since the forms indicating shelf and nearshore environments in the Bay of Biscay (Schnitker, 1969; Pujos-Lamy, 1973; Caralp, this vol.; Murray, 1971) are scarce in our samples. Also, abraded and damaged specimens of both benthic and planktonic foraminifers are infrequent. Hence, the large majority of the specimens in our samples appear to be more or less in situ for the upper slope in the northeastern Atlantic.

Numerous authors (Streeter, 1973; Schnitker, 1980; Lohman, 1978; Corliss, 1979a) have interpreted deepsea benthic foraminiferal taxic variations in terms of hydrolic parameters. Since the lithology in Cores 548-29 to $548-22$ is a fairly uniform muddy calcareous ooze, the variations in taxic abundances presented in Figure 4 should represent changes in hydrology for the middleto-late Pliocene transition in the intermediate depths of the northeastern Atlantic.

The benthic foraminiferal data in Figure 4 show a series of distinct events that can be interpreted as five stages in the evolution of intermediate-depth water properties over the middle-to-late Pliocene transition. These stages are described as follows:

1. Cores 548-29 and 548-28 contain abundant G. subglobosa, Cibicidoides, and Bulimina. Within Core 54829 there is a peak in the abundance of Ehrenbergina, ac- companied by a small peak in abundance for Uvigerina (dominantly U. peregrina). Within Core 548-28 there is a peak in the abundance of Pullenia.

2. In Core 548-27 the assemblage changes as the abundances of Cibicidoides and Bulimina decrease greatly and Cibicides, Melonis, and Pleurostomella become more abundant. Also in Core 548-27, the average size of the G. subglobosa populations becomes much more variable. There is probably a short break in the record at the boundary between Cores 548-27 and 548-26. At this point the gamma-ray intensity recorded in the downhole logs changes sharply (see Poag and Low, this vol.). Along with this change, the species composition of the planktonic foraminifers also changes sharply. Core 548-27 contains few G. puncticulata, but the species is abundant in Core 548-26. Finally, the boundary between Cores 548-27 and 548-26 is a "nick" point on many of the abundance curves for benthic taxa. All these changes coinciding indicates that at least some brief part of the record must be missing, even though no sedimentologic evidence was recovered indicating a hiatus.

3. In Cores 548-26 and 548-25, the abundance of $G$. subglobosa becomes quite variable and then decreases considerably from average values greater than $20 \%$ to values less than $10 \%$. Accompanying this pattern is a large drop in the average size of the $G$. subglobosa population, from values around $400 \mu \mathrm{m}$ to values less than $250 \mu \mathrm{m}$. Corresponding to these events, the abundance of Melonis, Bulimina, and Cibicidoides increase considerably. Abundances of Gyroidinoides and Ehrenbergina also increase somewhat over this interval. As shown in Figure 4, a progressive series of taxic abundance peaks occurs through Cores 548-26 and 548-25. The decrease 
Table 2. (Continued).

\begin{tabular}{|c|c|c|c|c|c|c|c|c|c|c|c|c|c|c|c|c|c|}
\hline \multirow[b]{2}{*}{$25-3,70$} & \multirow[b]{2}{*}{$25-3,139$} & \multirow[b]{2}{*}{$25-4,17$} & \multirow[b]{2}{*}{$26-1,40$} & \multirow[b]{2}{*}{$26-1,96$} & \multirow[b]{2}{*}{$26-1,148$} & \multirow{2}{*}{$26-2,60$} & \multicolumn{3}{|c|}{ Core-Section (level in $\mathrm{cm}$ ) } & \multirow[b]{2}{*}{$26-4,18$} & \multirow[b]{2}{*}{$27-1,4$} & \multirow[b]{2}{*}{$27-1,65$} & \multirow[b]{2}{*}{$27-1,85$} & \multirow[b]{2}{*}{$27-1,100$} & \multirow[b]{2}{*}{$28-1,24$} & \multirow[b]{2}{*}{$28-1,51$} & \multirow[b]{2}{*}{$28-1,104$} \\
\hline & & & & & & & $26-2,125$ & $26-3,50$ & $26-3,100$ & & & & & & & & \\
\hline 10.2 & 16.3 & $\underline{21.06}$ & 23.6 & 33.3 & 35.0 & 22.9 & 21.86 & 41.8 & 20.86 & 11.6 & 32.3 & 31.9 & 34.1 & $\underline{19.2}$ & $\underline{17.8}$ & $\underline{11.9}$ & 12.9 \\
\hline$\overline{-}$ & 0.47 & 1.19 & $\overline{-}$ & $\overline{0.23}$ & $\overline{1.1}$ & $\overline{0.52}$ & $\overline{0.77}$ & $\overline{0.71}$ & $\overline{0.71}$ & $\overline{0.24}$ & $\overline{0.33}$ & $\overline{-}$ & $\overline{0.5}$ & $\overline{0.2}$ & $=$ & $\overline{0.31}$ & - \\
\hline 3.2 & 1.41 & 5.04 & 2.33 & 3.8 & 3.2 & 3.1 & 2.64 & 2.48 & 2.49 & 4.7 & 13.8 & 24.1 & 17.5 & 19.5 & 3.1 & 3.7 & 2.3 \\
\hline 2.5 & 2.13 & 10.38 & 8.91 & 1.79 & 1.3 & 3.9 & 5.12 & 0.53 & 2.14 & 12.5 & $\overline{1.98}$ & $\overline{1.3}$ & $\overline{0.2}$ & $\overline{0.2}$ & 0.3 & 5.3 & - \\
\hline 3.2 & 0.95 & $\underline{13.9}$ & $\underline{18.99}$ & 9.2 & 4.7 & 5.2 & 4.03 & 6.91 & 4.18 & $\overline{1.4}$ & 6.6 & 3.7 & 5.8 & 5.6 & 4.8 & 1.25 & 4.2 \\
\hline 0.32 & - & 0.89 & 0.39 & - & 0.42 & - & 0.15 & 0.35 & 0.18 & 0.24 & - & 0.5 & 0.2 & - & 0.9 & 0.31 & - \\
\hline 1.9 & 0.24 & $\underline{7.72}$ & $\underline{11.24}$ & - & 0.85 & 3.91 & 8.68 & 2.84 & 6.24 & 4.5 & 0.99 & 5.8 & 0.9 & 1.8 & 1.4 & $\underline{13.1}$ & 6.1 \\
\hline 5.7 & 2.13 & $\overline{1.48}$ & $\overline{1.16}$ & 3.58 & 1.27 & 1.83 & 1.70 & 1.06 & 2.49 & 0.71 & 3.96 & 2.1 & 3.7 & 4.9 & $\underline{14.1}$ & $\overline{15.0}$ & 10.9 \\
\hline 2.5 & 4.02 & 2.97 & 4.65 & 4.70 & 7.6 & 3.65 & 8.06 & 7.27 & 6.77 & 6.6 & 11.9 & 6.8 & 7.4 & 15.2 & $\overline{4.5}$ & $\overline{7.8}$ & $\overline{6.1}$ \\
\hline 1.3 & 0.95 & 2.37 & 3.1 & 3.13 & $\overline{5.3}$ & 2.34 & 3.88 & 2.13 & 5.17 & 2.6 & $\overline{1.32}$ & 3.4 & 5.8 & $\overline{5.6}$ & 6.8 & $\overline{3.4}$ & 9.7 \\
\hline$\overline{-1}$ & 0.24 & - & 0.39 & 0.45 & 1.3 & - & 1.39 & 1.42 & 1.6 & 0.24 & 0.33 & 1.6 & 1.8 & 1.1 & 1.4 & 0.63 & 1.9 \\
\hline 2.2 & 0.71 & 1.78 & 3.1 & 2.23 & 5.1 & 1.82 & 1.39 & 1.95 & 4.28 & 3.1 & 1.98 & 3.7 & 2.7 & 2.0 & 5.5 & 2.8 & 7.4 \\
\hline- & 0.95 & 0.29 & 1.2 & 0.22 & - & 1.3 & - & 0.35 & - & - & - & 1.8 & 0.5 & 3.1 & 1.1 & - & $\overline{1.9}$ \\
\hline 0.63 & 1.18 & 1.18 & 0.77 & 0.89 & - & 0.26 & 0.31 & 3.19 & 0.53 & 0.24 & 0.99 & 1.6 & 1.2 & 1.8 & 0.6 & - & 2.2 \\
\hline- & - & - & - & - & - & - & - & - & - & - & 0.99 & - & - & - & - & - & - \\
\hline 2.2 & 3.1 & 1.19 & - & 0.22 & 0.64 & 0.78 & 0.31 & 0.71 & 0.71 & 0.24 & - & - & - & - & - & - & - \\
\hline 5.7 & $\underline{9.2}$ & 2.97 & 1.55 & 1.57 & 2.3 & 3.13 & 0.31 & 0.89 & 1.78 & 1.2 & - & - & - & - & - & - & - \\
\hline$\underline{38.1}$ & $\underline{31.0}$ & 6.82 & 8.14 & $\underline{14.7}$ & $\underline{11.7}$ & $\underline{29.9}$. & $\underline{19.38}$ & 5.85 & $\underline{22.28}$ & $\underline{39.5}$ & 0.33 & - & - & 0.2 & - & - & - \\
\hline$\overline{0.63}$ & $\overline{0.95}$ & 0.29 & $\overline{-}$ & $\overline{1.1}$ & $\overline{1.9}$ & $\overline{1.56}$ & $\overline{-}$ & - & $\overline{-}$ & $\overline{0.24}$ & 1.65 & 5.3 & 5.3 & 6.5 & 7.6 & 6.6 & 9.7 \\
\hline 6.9 & 8.3 & 2.97 & 1.55 & $\underline{9.4}$ & 7.6 & $\underline{5.9}$ & 6.98 & 4.43 & & & & & & & & & \\
\hline- & 1.18 & 0.89 & 1.16 & $\overline{3.58}$ & $\overline{1.27}$ & $\overline{2.86}$ & 1.70 & 7.65 & 4.1 & 3.3 & 4.62 & 1.1 & 0.5 & 0.5 & 2.6 & 0.63 & 2.6 \\
\hline 0.95 & 0.47 & 1.48 & 0.39 & 2.46 & 1.27 & 0.78 & 1.70 & $\overline{2.13}$ & 1.79 & - & 1.98 & - & 0.5 & 0.4 & 0.5 & 1.9 & 0.6 \\
\hline 9.2 & $\underline{11.6}$ & 4.74 & 3.1 & 2.01 & 3.4 & 0.78 & 6.51 & 2.66 & 4.1 & - & 0.66 & 1.6 & - & 0.2 & - & - & \\
\hline 0.32 & $\overline{1.65}$ & - & 0.39 & 0.45 & 0.43 & 0.26 & 0.15 & - & - & - & 1.32 & 0.5 & 3.7 & 7.6 & 0.5 & - & - \\
\hline 1.9 & 0.95 & 3.26 & 1.16 & 1.34 & 1.7 & 0.78 & 0.46 & 1.77 & 3.92 & 5.2 & 12.54 & & & & & & \\
\hline- & - & 2.97 & 1.55 & - & - & 0.52 & 2.02 & 2.30 & 0.18 & 0.48 & $\overline{0.33}$ & - & - & 0.2 & $\underline{11.8}$ & 7.8 & 15.1 \\
\hline- & - & - & - & - & - & - & - & - & 2.85 & - & - & 0.5 & 1.6 & $\overline{1.6}$ & $\overline{3.1}$ & $\overline{1.9}$ & 2.6 \\
\hline
\end{tabular}

Table 3. Description of Globorotalia puncticulata, Globorotalia inflata, and their intergrades for Cores 548-26 to 548-23.

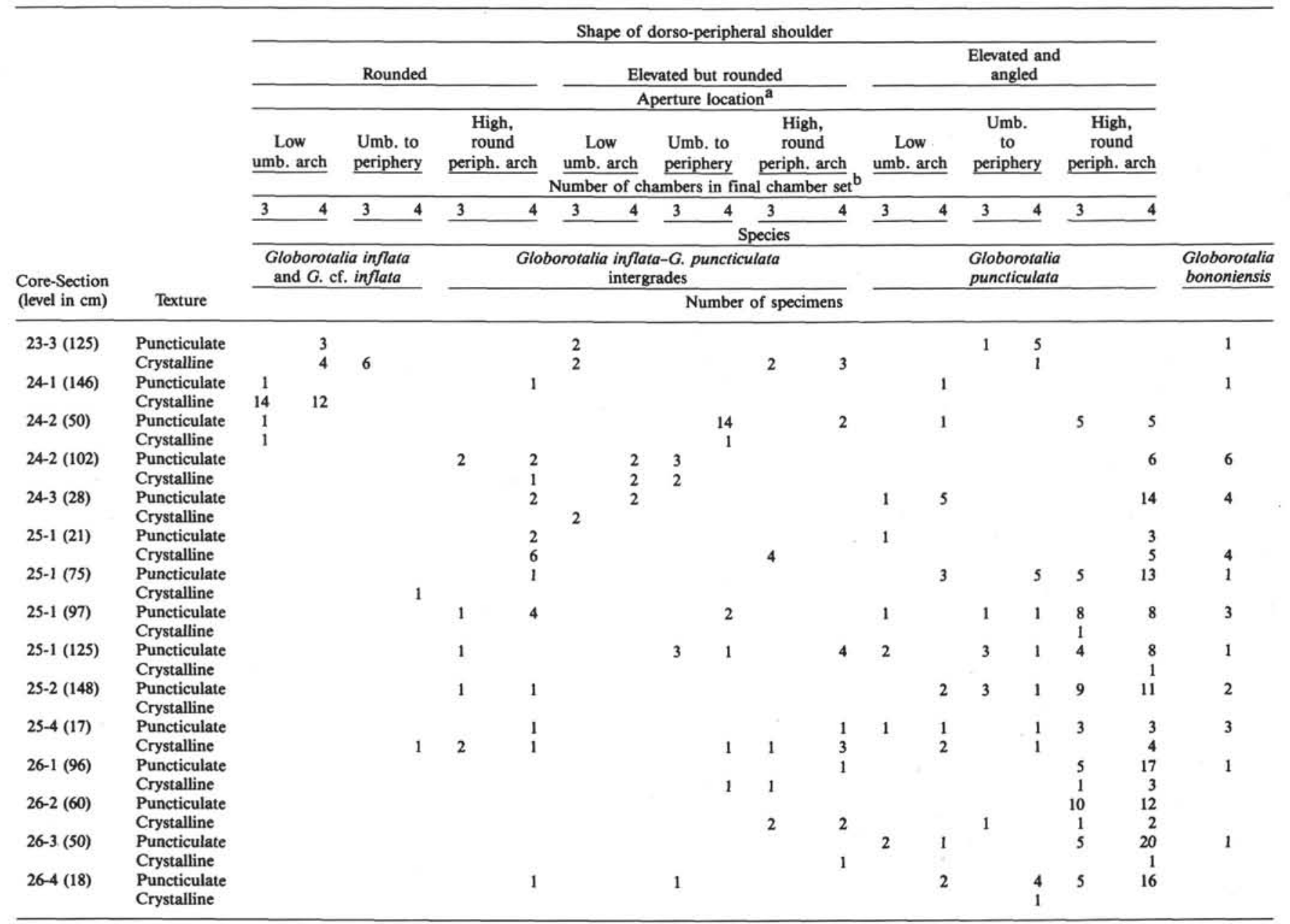

a Low umbilical arch; extending from umbilicus to periphery; high, round peripheral arch.

b As seen from spiral side, $3=3$ to $3.75,4=4$ to 4.5 . 
Table 4. Morphologic variability in the Globorotalia puncticulata group and abundances of dominant species $(\%)$, Hole 548 .

\begin{tabular}{|c|c|c|c|c|}
\hline $\begin{array}{l}\text { Core-Section } \\
\text { (level in } \mathrm{cm})\end{array}$ & $\begin{array}{l}\text { (G. inflata }+ \text { int. }) / \\
\text { G. puncticulata gp. }\end{array}$ & G. puncticulata gp. & $\%$ N. acostaensis (R.) & $\%$ N. pachyderma (R.) \\
\hline $23-3,125$ & 0.67 & 34.8 & 10.3 & 5.9 \\
\hline $24-1,100$ & 0.67 & 32.8 & 29.4 & 6.4 \\
\hline $24-1,146$ & 1.00 & 5.3 & 22.6 & 14.5 \\
\hline $24-2,50$ & 0.20 & 21.6 & 32.9 & 2.2 \\
\hline $24-2,102$ & 0.54 & 25.6 & 38.0 & 2.6 \\
\hline $24-3,45$ & 0.26 & 22.8 & 16.62 & 15.0 \\
\hline $24-3,97$ & - & 0.0 & 20.8 & 23.4 \\
\hline $25-1,21$ & 0.31 & 25.5 & 21.3 & 6.1 \\
\hline $25-1,75$ & 0.24 & 27.7 & 10.6 & 2.9 \\
\hline $25-1,125$ & 0.23 & 18.1 & 8.6 & 2.4 \\
\hline $25-2,0$ & 0.14 & 6.88 & 25.6 & 7.2 \\
\hline $25-2,26$ & 0.25 & 15.44 & 21.8 & 3.9 \\
\hline $25-2,97$ & 0.10 & 5.85 & 24.7 & 14.6 \\
\hline $25-2,148$ & 0.06 & 47.2 & 21.0 & 5.6 \\
\hline $25-3,70$ & 0.13 & 43.8 & 10.2 & 3.2 \\
\hline $25-3,139$ & 0.23 & 40.2 & 16.3 & 0.95 \\
\hline $25-4,17$ & 0.30 & 9.79 & 21.06 & 13.9 \\
\hline $26-1,40$ & 0.16 & 9.69 & 23.6 & 18.99 \\
\hline $26-1,96$ & 0.10 & 16.27 & 33.3 & 9.2 \\
\hline $26-1,148$ & 0.16 & 14.0 & 35.0 & 4.7 \\
\hline $26-2,60$ & 0.09 & 33.0 & 22.9 & 5.2 \\
\hline $26-2,125$ & 0.02 & 19.69 & 21.86 & 4.0 \\
\hline $26-3,50$ & 0.13 & 6.7 & 41.8 & 6.9 \\
\hline $26-3,100$ & 0.07 & 24.06 & 20.86 & 4.2 \\
\hline $26-4,18$ & 0.03 & 40.7 & 11.6 & 1.4 \\
\hline $27-1,4$ & 0.0 & 0.3 & 32.3 & 6.6 \\
\hline $27-1,65$ & - & 0.0 & 31.9 & 3.7 \\
\hline $27-1,85$ & - & 0.0 & 34.1 & 5.8 \\
\hline $27-1,100$ & 0.0 & 0.2 & 19.2 & 5.6 \\
\hline
\end{tabular}

in the size and abundance of $G$. subglobosa is accompanied initially by abundance peaks for Melonis and Bulimina. This is followed sequentially by peaks for Cibicidoides, Ehrenbergina, and finally Uvigerina. Clearly the mid-depth water-mass characteristics were evolving progressively over the interval represented by Cores $548-26$ and $548-25$.

4. In Core 548-24, corresponding to the first common occurrence of $G$. inflata, $G$. subglobosa once again becomes abundant, and average population size becomes large. Also, there is a peak in the abundances of Ehrenbergina and Uvigerina peregrina.

5. In Cores 548-23 and 548-22, U. peregrina is replaced by other Uvigerina species, chiefly $U$. auberiana d'Orbigny. Ehrenbergina disappears completely from the record. This interval is marked by abundant, large $G$. subglobosa and common Uvigerina. In addition, the abundances of Melonis, Bulimina, and Cibicidoides are quite variable, and the abundance of Pullenia is cyclic.

The ecology of most deep-sea benthic foraminiferal species is not well understood, so exact interpretation of the variations in abundance just described is not easy. The size variation in G. subglobosa is also hard to interpret, though it must represent changes in some aspect of the benthic environment, since the size measurements show very clear trends. Corliss (1979b) examined $G$. subglobosa sizes in specimens from the Indian Ocean, and found size trends to be related to water depth in some fashion. He was unable, however, to determine exactly what variable was affecting individual size in the
G. subglobosa population. He hypothesized that calcite dissolution could be an important factor, but this is not likely to be true for the Site 548 Pliocene, which has a very well preserved calcareous-sediment record. The variations in benthic taxa detailed in the foregoing may indicate changes in both water temperature and chemistry. To establish which of these factors was most important, we analyzed a subset of our samples for stable isotopes.

\section{ISOTOPE RESULTS: BENTHIC FORAMINIFERS}

To help evaluate the hydrology of the bottom waters at Site 548 during the middle-to-late Pliocene transition, we analyzed the stable isotopes of benthic foraminifers from 20 samples taken in Cores 548-28 to 548-24. These analyses used 20 to 80 individuals of either Globocassidulina subglobosa or Cibicidoides sp. The samples were prepared in the standard manner (Keigwin, 1979). They were reacted at $50^{\circ} \mathrm{C}$ with $100 \%$ orthophosphoric acid, and the stable isotopes of the carbon dioxide gas trapped from this were measured using a Varian Mat 250 mass spectrometer and the standard NBS-20. All measurements were converted to the PDB standard using the equation of Garlick (1978). As part of the analysis, routine small aliquots of the standards were run along with our samples through our preparation line to ensure consistency of results. Repeated experiments with NBS-20 and our laboratory standard Phi-1, which has been calibrated to PDB by the National Bureau of Standards, give a measurement precision to within $\pm 0.1 \%$ for $\delta^{18} \mathrm{O}$ and within $\pm 0.05 \%$ for $\delta^{13} \mathrm{C}$. The isotope measure- 
ments are presented in Table 5. The $\delta^{18} \mathrm{O}$ measurements show a periodic oscillation of about $0.5 \%$ and a mean value of $2.97 \%$.

These data cannot be converted directly to a temperature estimate, since the isotopic composition of northeastern Atlantic waters during the Pliocene is not known. Our data can be compared with other work from the deep Pacific and Atlantic, however, and a general statement about bottom-water temperatures at Site 548 can be made. The average oxygen-isotope value from Table 5 can be directly compared to the average value in the late Pliocene for the deep equatorial Pacific, as reported by Shackleton and Opdyke (1977). Their study is based on G. subglobosa, the same species as used in this report. The data from Table 5 may also be compared to the data of Keigwin (1982b) for the Pliocene of the Colombian Basin in the low-latitude North Atlantic (Site 502). It should be noted immediately that the values of the data for Site 548 are only $0.7 \% 0$ lighter than those for the deep Pacific, and they are nearly the same as the values obtained for the late Pliocene of the deep Atlantic. Thus, during the middle-to-late Pliocene transition, a site at about $1200 \mathrm{~m}$ depth in the northeastern Atlantic had nearly the same range of isotopic values as sites

Table 5. Isotopic measurements for the middle-to-late Pliocene transition (Hole 548), referred to PDB standard.

\begin{tabular}{|c|c|c|c|}
\hline $\begin{array}{l}\text { Core-Section } \\
\text { (level in } \mathrm{cm})\end{array}$ & Taxon & $\delta^{18} \mathrm{O}$ & $\delta^{13} \mathrm{C}$ \\
\hline $24-1,100$ & Globocassidulina subglobosa & 3.40 & -0.08 \\
\hline $24-2,50$ & G. subglobosa & 3.17 & -0.20 \\
\hline $24-3,45$ & G. subglobosa & 2.87 & 0.19 \\
\hline \multirow[t]{2}{*}{$25-1,95$} & G. subglobosa & 3.29 & -0.52 \\
\hline & Cibicidoides sp. & 2.63 & 0.68 \\
\hline $25-2,0$ & Cibicidoides sp. & 2.48 & 0.41 \\
\hline $25-2,26$ & Cibicidoides sp. & 1.8 & 0.49 \\
\hline $25-3,70$ & Cibicidoides sp. & 1.88 & 0.64 \\
\hline $26-1,96$ & Cibicidoides sp. & 1.95 & 0.59 \\
\hline $26-2,25$ & G. subglobosa & 2.77 & -0.01 \\
\hline $26-2,71$ & G. subglobosa & 3.07 & 0.20 \\
\hline $26-2,160$ & G. subglobosa & 3.19 & 0.24 \\
\hline $26-3,0$ & G. subglobosa & 3.31 & 0.24 \\
\hline $27-1,65$ & G. subglobosa & 3.28 & 0.07 \\
\hline $27-1,85$ & G. subglobosa & 2.98 & -0.21 \\
\hline $27-1,100$ & G. subglobosa & 3.04 & -0.14 \\
\hline $27-2,126$ & G. subglobosa & 3.26 & 0.03 \\
\hline \multirow[t]{3}{*}{$27-3,20$} & G. subglobosa & 3.13 & 0.05 \\
\hline & Cibicidoides sp. & 2.19 & 0.58 \\
\hline & Cibicidoides sp. & 2.17 & 0.52 \\
\hline $27-3,75$ & G. subglobosa & 3.46 & -0.03 \\
\hline $28-1,24$ & G. subglobosa & 2.77 & 0.13 \\
\hline \multirow[t]{2}{*}{$28-3,24$} & G. subglobosa & -2.82 & 0.24 \\
\hline & & $\bar{X}=2.97^{\mathrm{a}}$ & 0.24 \\
\hline
\end{tabular}

${ }^{\text {a }}$ Cibicidoides values converted to a $G$. subglobosa equivalent by adding $0.5 \%$ (after Graham et al., 1981). in the deep Pacific and Atlantic oceans. This is unusual, since the upper-slope region around Site 548 is today bathed by waters generated in the western Mediterranean (Sverdrup, Johnson, and Fleming, 1942) and having temperatures ranging between 6 and $9^{\circ} \mathrm{C}$ (U.S. Naval Oceanographic Atlas for the North Atlantic, 1967). This contrasts with a temperature of about $1^{\circ} \mathrm{C}$ for the deep Pacific in the region of the core studied by Shackleton and Opdyke (Defant, 1961). In Table 6, an average isotopic difference between Site 548 and the Pacific site, for modern oceanic conditions, is calculated using standard procedures. The difference is about $1.6 \%$, or twice as large as the difference recorded for the period of the the middle-to-late Pliocene transition. The Pacific isotopic record shows only a moderate, gradual increase in average value through the late Pliocene and Pleistocene. The increase can be associated with development of North Polar ice, and it seems likely that deep-Pacific water temperature in the Pliocene was not much different from the present one. Thus, it seems probable that the water flowing over Site 548 during the middle to late Pliocene was much colder than the western Mediterranean water now bathing the region. In the Colombian Basin (Site 502), ${ }^{18} \mathrm{O}$ values for $C$. wuellerstorfi average $2.07 \%$ over the interval from about $3.1 \mathrm{~m}$.y. ago to the Plio-Pleistocene boundary (12 samples averaged from Keigwin, 1982b). This value can be compared to the average for Site 548 by adding about $0.5 \%$ to the $C$. wuellerstorfi analyses to get a $G$. subglobosa equivalent (Graham et al., 1981). When this is done, given the limitations of the averaging process, the average for Site 548 is similar to the value for Site 502. The deep Atlantic Ocean was undoubtably cold during the late Pliocene (Keigwin, 1982a), so the data cited here indicate that the waters flowing over Site 548 during the interval represented by our samples were cold. Hence, during the middle-to-late Pliocene transition, warm, saline Mediterranean water was not flowing through the northeastern Atlantic.

This conclusion is supported by the benthic foraminiferal populations described earlier. The samples contain abundant G. subglobosa and Cibicidoides kullenbergi (Parker). Both these species are associated with colder waters (Schnitker, 1974, 1979a). Neither is present in the Holocene samples from Site 548 (Caralp, this vol.), which represent warm water.

\section{CONCLUSIONS}

1. The Pliocene section at Site 548 is a hemipelagite in which the greatest variation in grain size occurs in the

Table 6. Calculation of oxygen isotopic difference $(\%)$ between the deep Pacific and Site 548 at the present day.

\begin{tabular}{|c|c|c|c|c|c|c|}
\hline (a) Site & $\begin{array}{c}\text { Water } \\
\text { temperature }\left({ }^{\circ} \mathrm{C}\right)^{\mathrm{a}}\end{array}$ & Salinity ${ }^{a}$ & $w^{\mathrm{a}}$ & Calculated $\Delta_{\text {calcite }}$ & $\begin{array}{l}\text { Recent } \\
\Delta\end{array}$ & $\begin{array}{c}\text { mid-Plio. } \\
\Delta\end{array}$ \\
\hline $\begin{array}{l}548 \\
\text { Equatorial Pacific }\end{array}$ & $\begin{array}{l}7.0 \\
1.0\end{array}$ & $\begin{array}{l}35.4 \\
34.7\end{array}$ & $\begin{array}{l}-0.3 \\
-0.5\end{array}$ & $\begin{array}{l}2.33 \\
3.90\end{array}$ & 1.57 & 0.72 \\
\hline
\end{tabular}

a Temperatures and salinities from U.S. Naval Oceanographic Atlas for the North Atlantic (1967) and Defant

(1961). Associated ${ }^{18} \mathrm{O}$ values for the water from Epstein et al. (1951).

b Location $4^{\circ} 37^{\prime} \mathrm{N}, 139^{\circ} 36^{\prime} \mathrm{W}$ (Shackleton and Opdyke, 1977).

Mean ${ }^{18} \mathrm{O}$ from Gauss upper boundary to $3.2 \mathrm{~m} . \mathrm{y}$. $=3.69 \%$. 


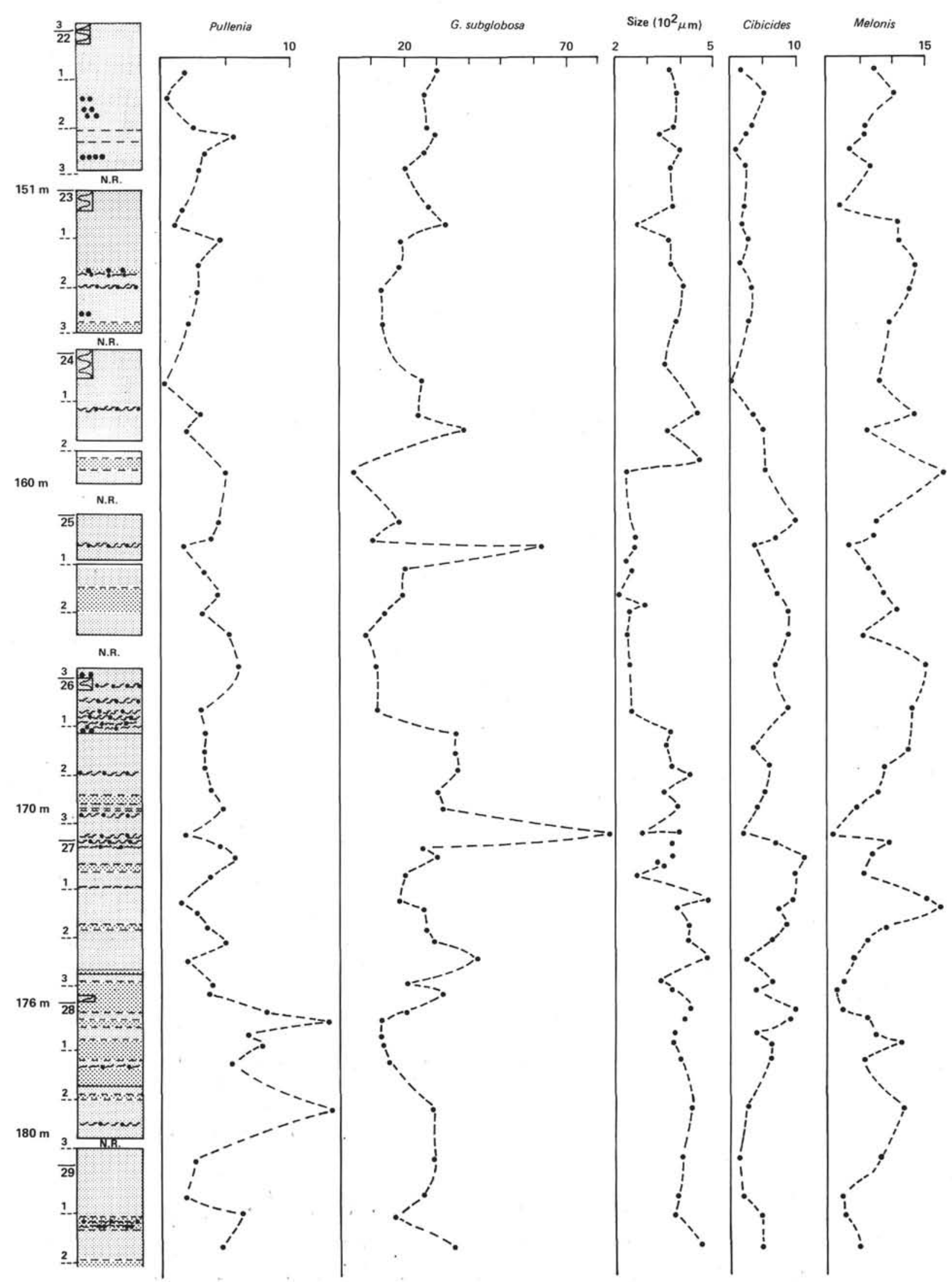

Figure 4. Relative abundances of benthic foraminiferal genera and species over the interval spanning the first occurrence of $G$. inflata. Size = mean test size of $G$. subglobosa population. Shaded area = abundance of $U$. peregrina. Numbers at far left as in Figure 2. 
MIDDLE-TO-LATE PLIOCENE TRANSITION

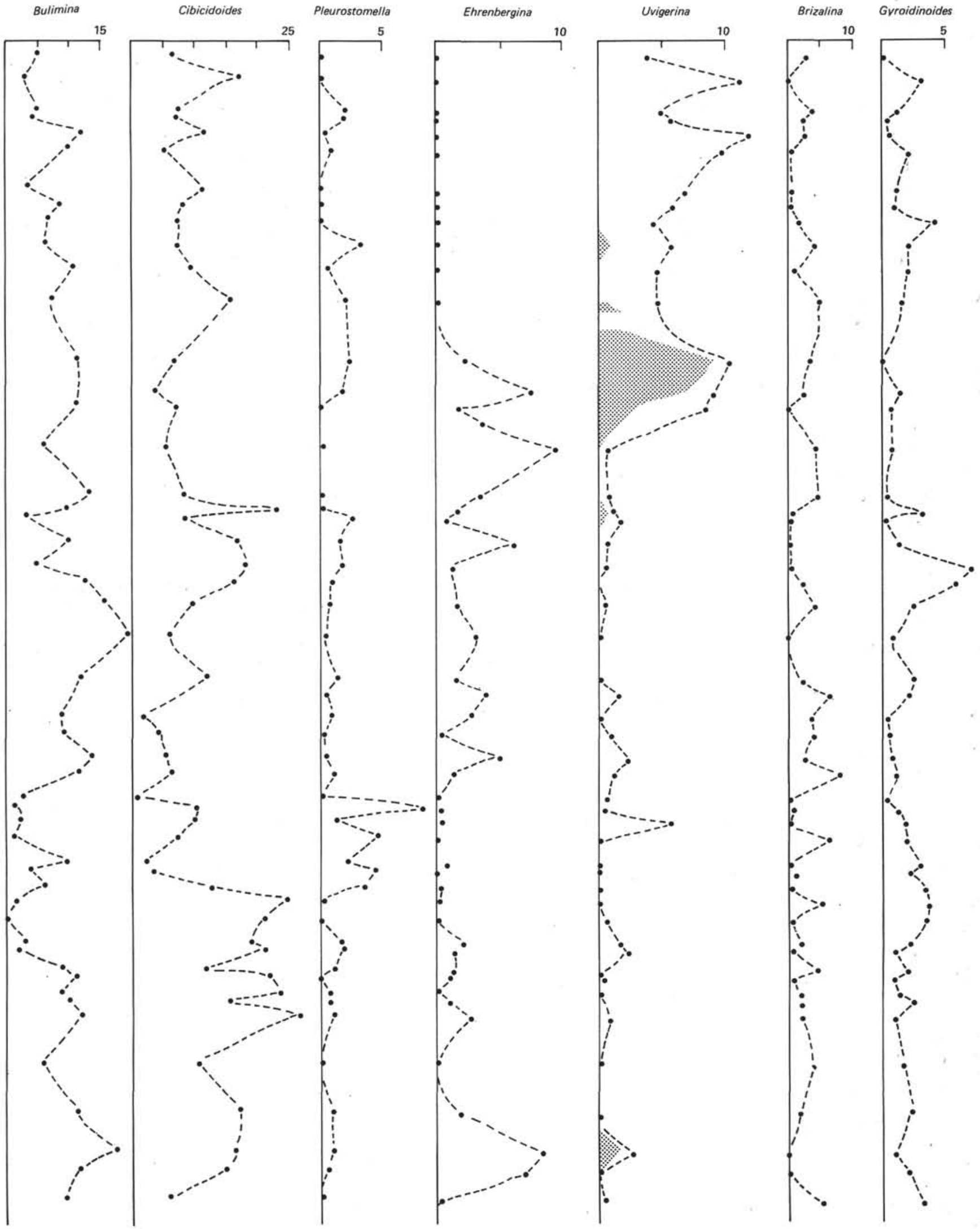

Figure 4. (Continued). 
63- to $32-\mu \mathrm{m}$ and $<2-\mu \mathrm{m}$ fractions. This variation results from fluctuations in the input of terrigenous quartz and calcite to the $63-$ to $32-\mu \mathrm{m}$ fraction of the sediments. Since this input is not related to any sedimentary structures, it must have been accomplished by a pelagic settling process.

2. The evolutionary appearance of Globorotalia inflata is recorded at Site 548 within Cores $548-25$ and 548-24. Over this interval, species abundances is the planktonic assemblages fluctuate periodically indicating significant oscillatory, lateral displacements of surface water masses in the northeastern Atlantic Ocean.

3. During the mid- to late Pliocene the intermediatedepth water mass was undergoing a series of progressive changes represented by changes in the benthic foraminiferal assemblages. These changes particularly affected Globocassidulina subglobosa, Uvigerina, and Ehrenbergina. The appearance of $G$. inflata was marked by a peak in abundance of both Ehrenbergina and Uvigerina peregrina. These taxa are associated with waters of lower oxygen content and with sediments richer in organic carbon (Lohman, 1978; Miller and Lohmann, 1982). So it seems possible that there was a reduction in the oxygen content of intermediate waters of the northeastern Atlantic during the middle-to-late Pliocene transition. After this event, Ehrenbergina disappears from the record, and Uvigerina species become common in benthic assemblages.

4. Oxygen-isotope data and benthic foraminiferal species abundances show that the water bathing Site 548 during the middle-to-late Pliocene transition was cold. This contrasts markedly with the present-day situation, in which warm, saline Mediterranean water flows over Site 548. Hence, during the middle to late Pliocene, the thermal structure of the North Atlantic Ocean was different from that of the present. The foregoing observations support, in part, Benson's (1972) study of the Pliocene Mediterranean. On the basis of ostracode assemblages, he shows that the deep Mediterranean was cold during the Pliocene. Benson's model of Pliocene temperatures in the western Mediterranean would make it an unlikely source for warm, saline waters that could invade the intermediate-depth Atlantic. However, in that model (1972, fig. 7), the eastern Mediterranean would have been a possible source for warm, saline water, since this region was apparently a warm, sill-protected, deep basin. Our data indicate that eastern Mediterranean water was not present at intermediate depths in the northeastern Atlantic over the Pliocene time interval we have studied. Thus, the intermediate-depth water in the northeastern Atlantic during the middle to late Pliocene probably had its source in the Atlantic or Arctic basin.

5 . The isotopically estimated bottom-water temperature for Site 548 did not change very much over the time spanning the first appearance of $G$. inflata (variation of about $0.5 \%$ ). So the changes in abundances of benthic taxa observed over this interval can be interpreted as indicating that the intermediate-depth water mass underwent progressive chemical, rather than thermal, evolution.

\section{ACKNOWLEDGMENTS}

The authors thank the Graduate School at Northern Illinois University for support which allowed the senior author to travel to Lamont-Doherty Geological Observatory to collect samples and make observations necessary for this chapter. The manuscript benefited from reviews by Drs. R. Poore and C. W. Poag and reviewers selected by Dr. Poag.

\section{REFERENCES}

Backman, J., 1979. Pliocene biostratigraphy of DSDP Sites 111 and 116 from the North Atlantic Ocean and the age of Northern Hemisphere glaciation. Stockholm Contrib. Geol., 32:115-137.

Bé, A., 1977. An ecological, zoogeographic and taxonomic review of recent planktonic Foraminifera. In Ramsey (Ed.), Oceanic Micropaleontology (Vol. 1): London (Academic Press), pp. 1-100.

Benson, R., 1972. Ostracodes as indicators of threshold depth in the Mediterranean during the Pliocene. In Stanley, D. (Ed.), The Mediterranean Sea: A Natural Sedimentation Laboratory: Stroudsburg, $\mathrm{Pa}$. (Dowden, Hutchinson and Ross), pp. 63-74.

Berggren, W. A., 1972a. Cenozoic biostratigraphy and paleobiologeo- graphy of the North Atlantic. In Laughton, A. S., Berggren, W. A., et al., Init. Repts. DSDP, 12: Washington (U.S. Govt. Printing Office), 965-1001.

1972b. Late Pliocene-Pleistocene glaciation. In Laughton, A. S., Berggren, W. A., et al., Init. Repts. DSDP, 12: Washington (U.S. Govt. Printing Office), 953-963.

Berggren, W., and Van Couvering, J., 1974. The late Neogene: biostratigraphy, geochronology and palaeoclimatology of the last 15 million years in marine and continental sequences. Palaeogeogr. Palaeoclimatol. Palaeoecol., 16:1-216.

Corliss, B., 1979a. Recent deep sea benthonic foraminiferal distributions in the southeast Indian Ocean: inferred bottom water routes and ecological implications. Mar. Geol., 31:115-138. $1979 \mathrm{~b}$. Size variation in the deep-sea benthonic foraminifer Globocassidulina subglobosa (Brady) in the southern Indian Ocean. J. Foraminiferal Res., 9:50-60.

Defant, A., 1961. Physical Oceanography (Vol. 1): New York (Pergamon Press).

Doyle, L., Pilkey, O., and Woo, C., 1979. Sedimentation on the eastern United States continental slope. In Doyle, L., and Pilkey, O. (Eds.), Geology of Continental Slopes. Spec. Publ., Soc. Econ. Paleontol. Mineral., 27:119-130.

Epstein, S., Buchsbaum, R., Lowenstam, H., and Urey, H., 1951. Carbonate-water isotopic temperature scale. Geol. Soc. Am. Bull., 62:417-426.

Garlick, G., 1978. The stable isotopes of oxygen. In Wedepohl, K., et al. (Eds.), Handbook of Geochemistry: New York (Springer-Verlag), pp. 8-B-1 to 8-B-27.

Graham, D., Corliss, B., Bender, M., and Keigwin, L., 1981. Carbon and oxygen isotopic disequilibria of Recent benthic Foraminifera. Mar. Micropaleontol., 6:483-497.

Keigwin, L., 1979. Late Cenozoic isotope stratigraphy and paleoceanography of DSDP sites from the east equatorial and central North Pacific Ocean. Earth Planet. Sci. Lett., 45:361-382.

1982a. Isotopic paleoceanography of the Caribbean and east Pacific: role of Panama uplift in late Neogene time. Science, 217:350-353.

, 1982b. Stable isotope stratigraphy and paleoceanography of Sites 502 and 503. In Prell, W. L., Gardner, J. V., et al., Init. Repts. DSDP, 68: Washington (U.S. Govt. Printing Office), 445-453.

Loeblich, A., and Tappan, H., 1964. Sarcodina. In Moore, T. C., Jr. (Ed.), Treatise on Invertebrate Paleontology, Part C, Protista 2 (Vols. 1 and 2): Lawrence (Univ. Kansas Press).

Lohman, G., 1978. Abyssal benthonic Foraminifera as hydrographic indicators in the western South Atlantic Ocean. J. Foraminiferal Res., 8:6-34.

Loubere, P., 1982. The western Mediterranean during the last glacial: attacking a no-analog problem. Mar. Micropaleontol., 7:311-325.

Miller, K., and Lohmann, G., 1982. Environmental distribution of recent benthic foraminifera on the northeast United States continental slope. Geol. Soc. Am. Bull., 93:200-206. 
Murray, J., 1971. An Atlas of British Recent Foraminiferids: London (Heinemann Ed. Books).

Ness, G., Levi, S., and Couch, R., 1980. Marine magnetic anomaly timescales for the Cenozoic and Late Cretaceous: a précis, critique, and synthesis. Rev. Geophys. Space Phys., 18:753-770.

Poore, R., 1979. Oligocene through Quaternary planktonic foraminiferal biostratigraphy of the North Atlantic: DSDP Leg 49. In Luyendyk, B. P., Cann, J. R., et al., Init. Repts. DSDP, 49: Washington (U.S. Govt. Printing Office), 447-518.

1981. Temporal and spatial distribution of ice-rafted mineral grains in Pliocene sediments of the North Atlantic: implications for late Cenozoic climatic history. In Warme, J., Douglas, R., and Winterer, E. (Eds.), The Deep Sea Drilling Project: A Decade of Progress. Spec. Publ. Soc. Econ. Paleontol. Mineral., 32:505-515.

Pujos-Lamy, L., 1973. Répartition bathymètrique des foraminifères benthiques de Golfe de Gascogne. Comparaison avec d'autres aires océaniques. Rev. Esp. Micropaleontol., 5:213-234.

Reid, J., 1978. On the middepth circulation and salinity field in the North Atlantic Ocean. J. Geophys Res., 83:5063-5067.

Royce, C., 1970. An Introduction to Sediment Analysis (Arizona State University Press).

Schnitker, D., 1969. Distribution of Foraminifera in a portion of the continental shelf of the Golfe de Gascogne (Gulf of Biscay). Bull. Centre Rech. Pau SNPA, 3:33-64.

, 1974. West Atlantic abyssal circulation during the past 120,000 years. Nature, 248:285-387.

1979a. The deep waters of the western North Atlantic during the past 24,000 years, and the re-initiation of the western boundary undercurrent. Mar. Micropaleontol., 4:265-280. , 1979b. Cenozoic deep water benthonic foraminifera, Bay of Biscay. In Montadert, L., Roberts, D. G., et al., Init. Repts. $D S D P, 48$ : Washington (U.S. Govt. Printing Office), 377-413.

1980. Quaternary deep sea benthic Foraminifera and bottom water masses. Ann. Rev. Earth Planet. Sci., 8:343-370.

Shackleton, N., and Opdyke, N., 1977. Oxygen isotope and paleomagnetic evidence for early Northern Hemisphere glaciation. $\mathrm{Na}$ ture, 270:216-219.

Stainforth, R., Lamb, J., Luterbacher, H., Beard, J., and Jeffords, R., 1975. Cenozoic planktonic foraminiferal zonation and characteristics of index forms. Article 62, Univ. Kan. Paleontol. Inst., U. Kansas Press, Lawrence, Kansas.
Streeter, S., 1973. Bottom water and benthonic Foraminifera in the North Atlantic: glacial-interglacial contrasts. Quat. Res., 3: 131-141.

Sverdrup, H., Johnson, M., and Fleming, R., 1942. The Oceans: New York (Prentice-Hall).

U.S. Naval Oceanographic Atlas of the North Atlantic, 1967. Section 2: Physical Properties: Washington (U.S. Naval Oceanographic Office).

Date of Initial Receipt: February 3, 1983

Date of Acceptance: July 1, 1983

\section{APPENDIX}

\section{Planktonic Foraminiferal Taxonomy}

The taxonomy used in Table 2 is that of Poore (1979) and of standard references on Recent planktonic foraminifers (e.g., Bé, 1977). Several varieties have also been recognized, since we encountered several forms that could not be assigned to established species, or which seemed likely to be paleoecologically useful. Photographs of these forms are presented in Plate 2. The forms are described here in order of appearance in Table 2, where they are identified by superscript a:

Neogloboquadrina sp. 1. This form is superficially similar to Globigerina bulloides, but it has a neogloboquadrinid texture. Also, its chambers and their arrangement are more quadrate than globular. The forms seen to date are dominantly left-coiling, and have a distinct lip along the aperture.

Globigerina bulloides, quadrate form. This form is similar to Globigerina bulloides in chamber arrangement and texture, but it has a distinctly quadrate chamber arrangement. Chambers appear more rectangular than round; sutures, on the umbilical side especially, are often deeply incised. The final chamber is not much larger than the penultimate chamber. This form has been called Globigerina incisa (Brönnimann and Resig) (C. W. Poag, pers. comm.).

Globigernia bulloides, inflated form. This form resembles Globigerina bulloides in chamber arrangement and texture, but its chambers are laterally inflated, so that the chamber length is greater than its height. These form are generally rare.

Globorotalia bononiensis Dondi. This species resembles Globorotalia puncticulata in general morphology, and is discussed in Stainforth et al. (1975, p. 335). 


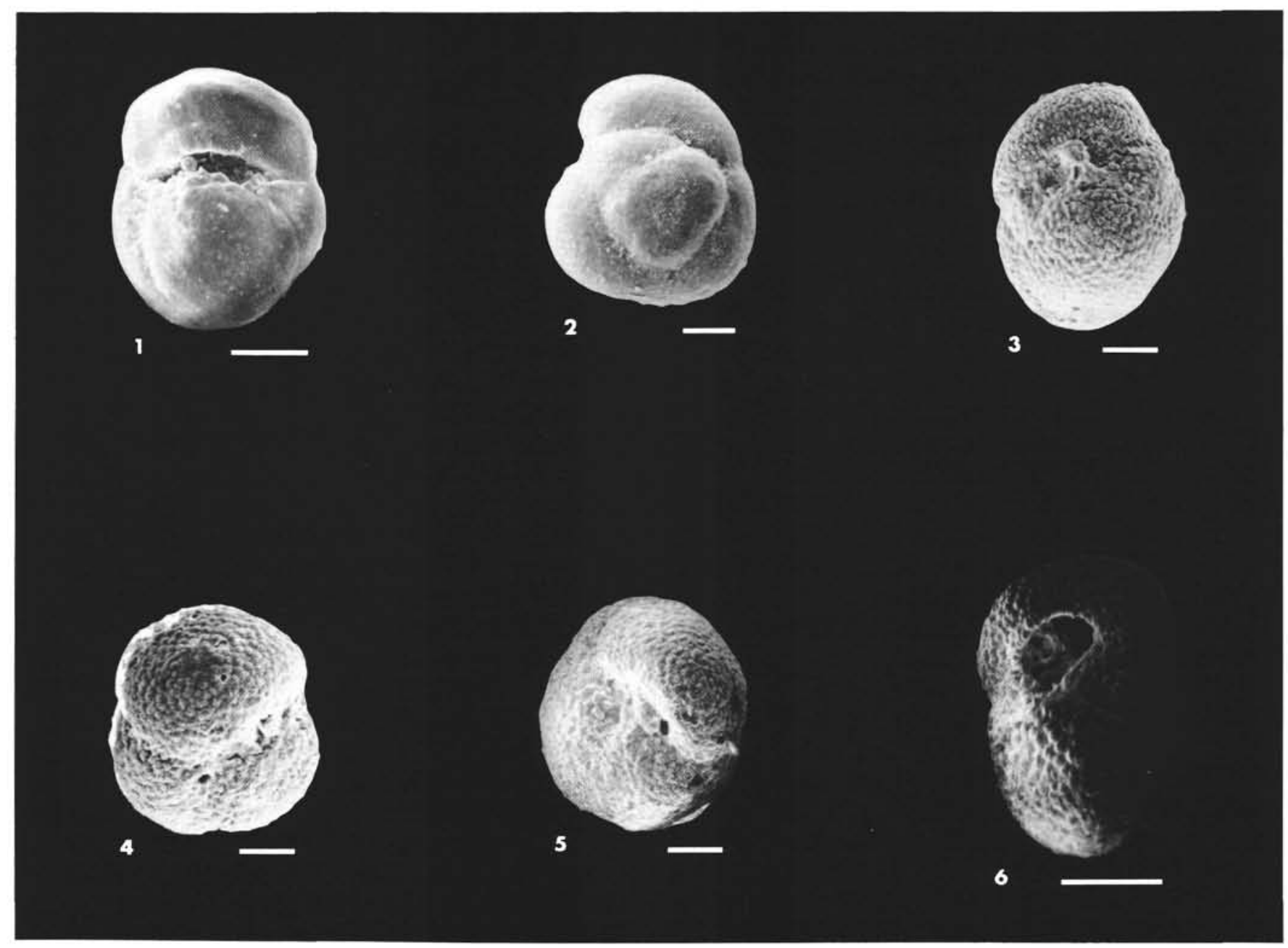

Plate 1. Pliocene-Pleistocene specimens of Globorotalia inflata and Globorotalia puncticulata. (All scale bars $=100 \mu \mathrm{m}$.) 1-5. G. inflata, (1-2) upper Pleistocene, Hole 549A (adjacent to Site 548), Sample 549A-2-6, $116 \mathrm{~cm}$ (1, view showing umbilical aperture; 2, view showing spiral side coiling with $3 \frac{1}{2}$ chambers in the final whorl), (3-4) lower Pleistocene, with crystalline texture, Sample 548-15-4, 128 cm; (5) upper Pliocene, Sample 548-24-1, $146 \mathrm{~cm}$. 6. G. puncticulata exhibiting arched interio-marginal aperture, Sample 548-26-4, $18 \mathrm{~cm}$. 


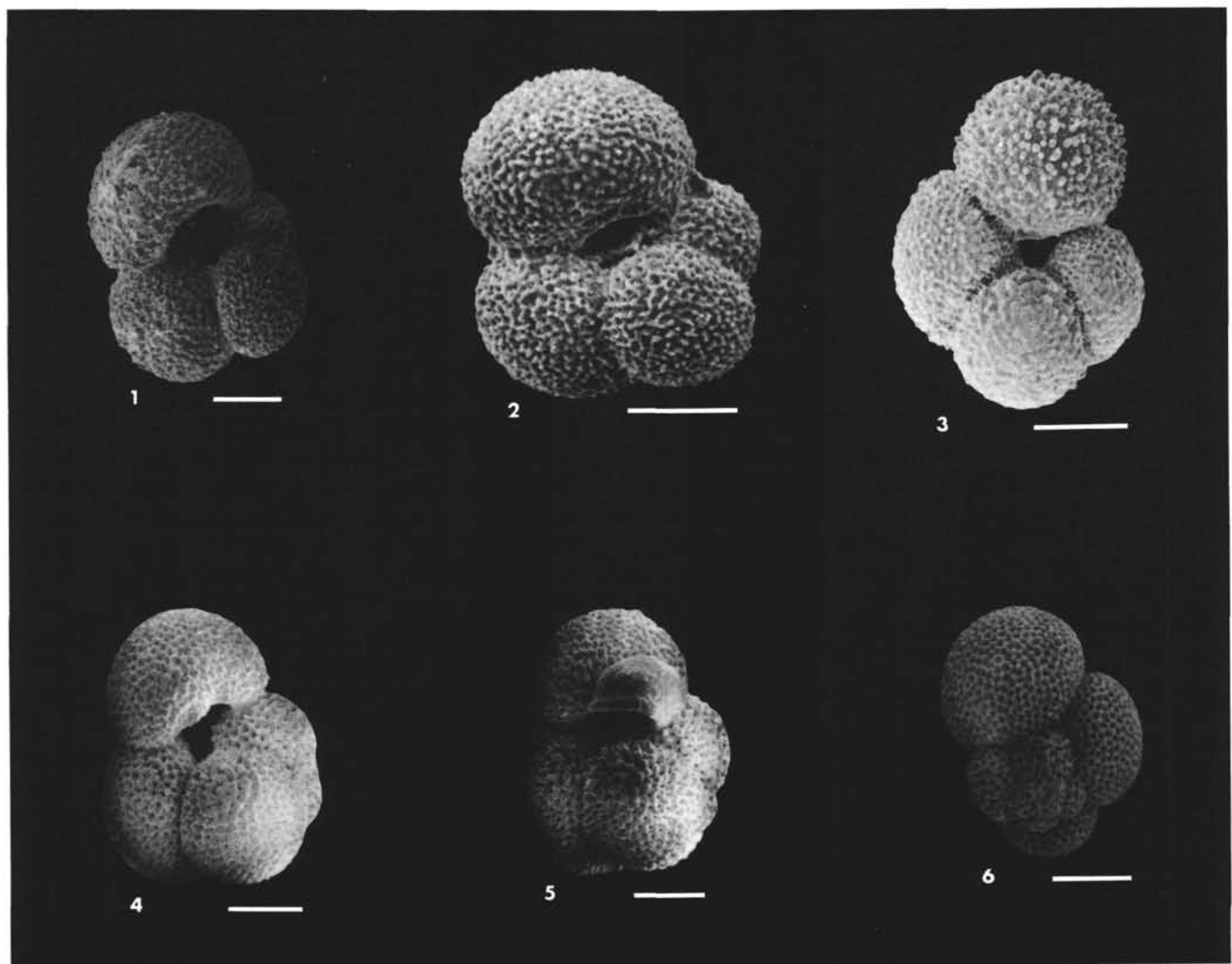

Plate 2. Selected planktonic upper Pliocene foraminifers at Site 548 (some forms are discussed in Appendix); all specimens taken from Sample 548$21-2,20 \mathrm{~cm}$. (All scale bars $=100 \mu \mathrm{m}$.) 1, 10. Globigerina bulloides, (10) closeup of penultimate chamber of Fig. 1, showing texture. 2. G. bulloides inflated form. 3. G. bulloides, quadrate form. 4, 6-7, 12. Gloloquadrina sp. 1, (7) higher magnification to show texture, (12) closeup of final chamber of Fig. 6, showing texture. 5. Kummerform Globoquadrina sp. 1. 8-9, 11. Globoquadrina venezuelana, (11) closeup of texture, penultimate chamber of Fig. 9. 


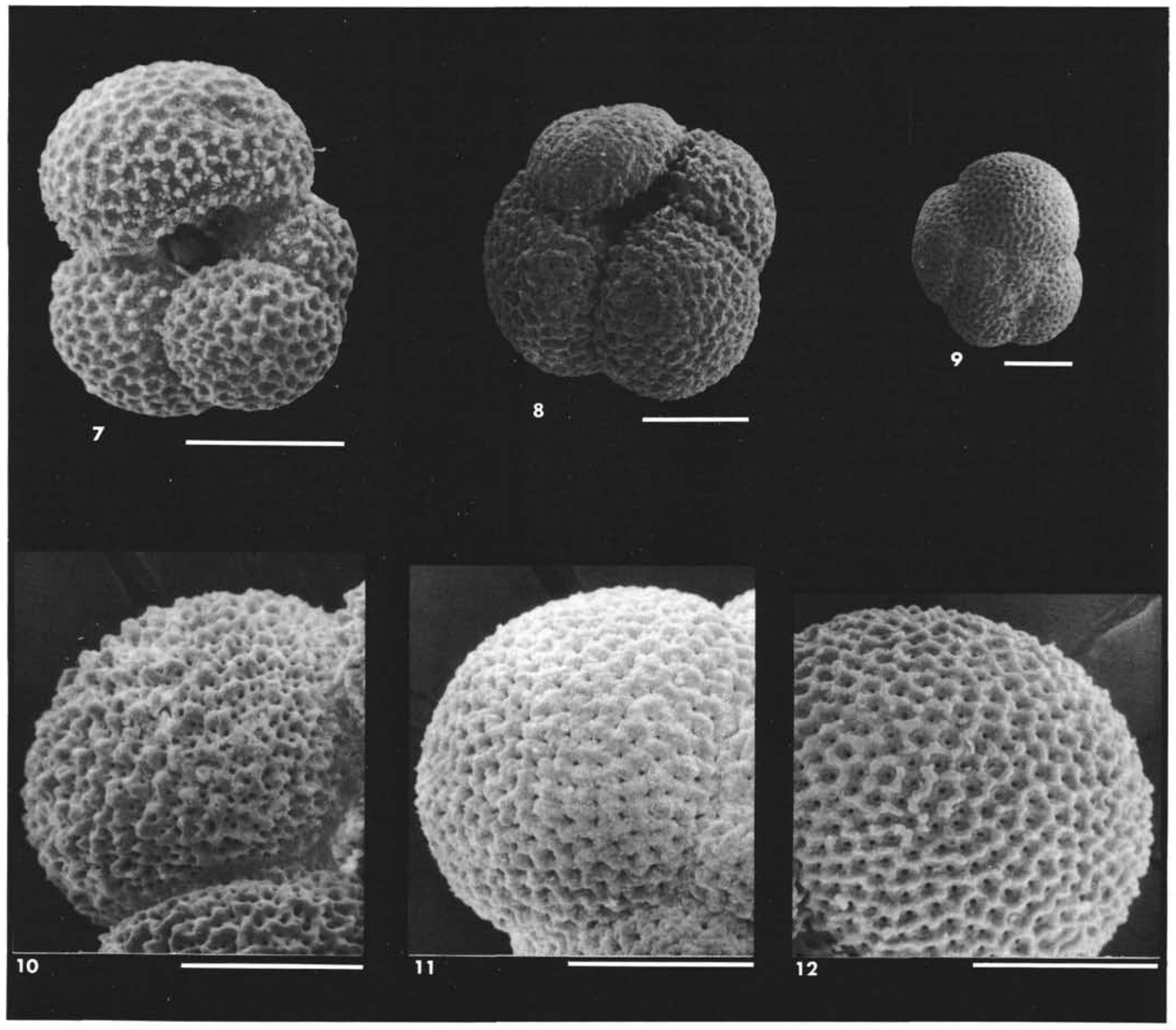

Plate 2. (Continued). 